\title{
TEORIJA KOMUNIKACIJSKEGA TUJEJEZIČNEGA IZOBRAŽEVANJA
}

\section{UVOD}

Jefim Izrailjevič Passov je ruski pedagog in didaktik, avtor več kot dvajsetih znanstvenih monografij in priročnikov ter ustvarjalec učbenikov za učenje različnih tujih jezikov (angleščine, nemščine, francoščine in ruščine). Passov je princip komunikativno zasnovanega pouka tujega jezika predstavil že leta 1969, in sicer na I. kongresu MAPRJAL (rus. МАПРЯЛ) - Mednarodne zveze učiteljev ruskega jezika in literature - v Moskvi. Njegova metodična šola je na področju komunikacijskega pristopa pri učenju tujih jezikov tako ena izmed prvih glasnic omenjenega načina obravnave, ki pa je v zahodnem (anglosaksonskem) svetu skorajda povsem neznana, tudi v slovenskem prostoru se teorija ruskega didaktika praktično ne omenja. Teorija Passova je svoj razmah in močan vpliv na poučevanje tujih jezikov v sovjetskih šolah doživela predvsem v letih1980-1989 z reorganizacijo srednjega in višjega šolstva. V omenjenem obdobju so v proces poučevanja tujih jezikov uvedli komunikacijski pristop (I. A. Zimnjaja, E. I. Passov) in t. i. metodo aktivizacije (G. A. Kitajgorodskaja), začela so se izdajati dela o metodah poučevanja tujih jezikov, na novo so se oblikovali programi in učbeniki. Na podlagi omenjenih novih pristopov so se spremenili tudi skupni izobraževalni koncepti in dokumenti, ki se nanašajo na poučevanje tujih jezikov (npr. leta 1981 je nastal dokument Teoretične osnove metodike poučevanja tujih jezikov v srednjih šolah, leta 1982 pa Metodika poučevanja tujih jezikov v srednjih šolah). Po letu 1990 ostaja v ruskih šolah glavni cilj poučevanja tujih jezikov doseganje komunikacijske kompetence ob upoštevanju koncepta komunikacijskega tujejezičnega izobraževanja, ki ga je utemeljil ravno E. I. Passov. (Afanas'eva, 2012)

Leta 2010 je Passov skupaj s Kuzovljevo N. E. ustvaril obsežni monografiji - Urok inostrannogo jazyka in Osnovy kommunikativnoj teorii i tehnologii inojazyčnogo obrazova$n i j a-v$ katerih je predstavljena teorija t. i. tujejezičnega izobraževanja Passova in konkretni napotki, nasveti, učne oblike ter navodila za izdelavo različnih didaktičnih pripomočkov za pouk tujega jezika, pri oblikovanju katerih je sodelovala tudi N. E. Kuzovljeva.

$\mathrm{V}$ prispevku bomo podrobneje razložili nekatera teoretična izhodišča komunikacijske teorije Passova. 


\section{TUJEJEZIČNO IZOBRAŽEVANJE}

Razumevanje poučevanja tujega jezika kot komunikacijskega procesa je svoj razcvet doživelo v 20. stoletju, vendar lahko korenine, iz katerih izhaja teorija Passova, najdemo že v funkcionalni (direktni, naravni) metodi iz konca 19. stoletja. Funkcionalne metode težijo k praktični uporabi jezika v položajih, pomembnih za sporazumevanje. Jezika se učimo z rabo, ne pa z učenjem slovnice in slovničnih pravil, zato ima pri omenjenih metodah prednost govorjeni jezik in njegova praktično-funkcionalna raba. Vendar pa Passov v svoji teoriji ne izhaja iz predpostavke, po kateri se je tujega jezika mogoče naučiti tako hitro kot maternega, poleg tega se tujega jezika ne učimo s posnemanjem, ampak preko sistematično strukturiranega pouka, ki zajema principe situacijskosti, funkcionalnosti, individualizacije, novosti ter govorno-miselne dejavnosti.

Nekatere značilnosti teorije komunikacijskega tujejezičnega izobraževanja Passova izhajajo tudi iz neobehaviorističnih pogledov, ki med drugim temeljijo na sopostavljanju maternega in tujega jezika ter vključevanju kulturno-civilizacijskega znanja.

Potrebo po sporazumevanju ter povezovanju tujega jezika s čim resničnejšimi življenjskimi položaji oz. situacijami sta poudarjali tudi oralna in avdiovizualna metoda. (Vučo 2012)

Passov je vsa omenjena izhodišča nadgradil s konkretnimi napotki za delo v razredu (izdelava tabel in opor), z upoštevanjem spoznavnega, razvojnega, vzgojnega in učnega vidika, razumevanjem logike pouka tujega jezika ter s svojo humanistično usmerjenostjo, ki upošteva tujejezično kulturo, medkulturnost in oblikovanje celovite, duhovne osebnosti učencev. To pa so tudi izhodišča, ki jih upošteva Skupni evropski okvir smernic za učenje in poučevanje jezikov.

Passov v svojo komunikacijsko teorijo uvede nekaj novih pojmov, in sicer postavi jasno ločnico med pojmoma 'učenje' (rus. обучение) in 'izobraževanje' (rus. образование). Učenje zajema posredovanje znanja, zmožnosti uporabnika jezika, da izvaja jezikovne dejavnosti (govor, branje, pisanje, poslušanje), medtem ko izobraževanje vključuje poleg omenjenega tudi razvojno in vzgojno plat pouka. Izobraževanje stremi k oblikovanju človeka, ki ga Passov imenuje 'duhovni individuum'. V procesu izobraževanja je učenec subjekt, ki aktivno sodeluje pri usvajanju novega znanja (v procesu učenja je učenec objekt). Passov zato predlaga, da namesto besedne zveze učenje tujih jezikov uporabljamo termin tujejezičnо izobraževanje (rus. иноязычное образование). Cilj omenjenega izobraževanja je človek sam, razvoj njegove duhovnosti, sposobnosti, moralna vzgoja ipd. Vsebina takšnega izobraževanja je kultura, sestavljena iz štirih komponent: vedeti - znati - ustvarjati - želeti delovati. Zadnji dve komponenti sta najpomembnejši, kar principialno loči učenje, ki poudarja znanje in s tem spoznavni vidik, od tujejezičnega izobraževanja. (Passov, Kuzovleva 2010)

Tujejezično izobraževanje vsebuje štiri vidike, ki med seboj niso ločeni in jih ne smemo razumeti kot samostojne enote, ampak so med seboj tesno prepleteni. Omenjeni štirje vidiki so: 
- $\quad$ spoznavni vidik, ki zajema vedenje o tuji kulturi in jeziku ter dialog med kulturama;

- $\quad$ razvojni vidik, pri katerem gre za razvoj sposobnosti in veščin, ki jih učenec potrebuje za govorno produkcijo, komunikacijo, učenje in druge dejavnosti;

- vzgojni vidik, ki predstavlja oblikovanje nravstvenih lastnosti učencev in vrednot, kot so duhovnost, multikulturnost, humanizem, patriotizem, etika in estetika ter

- učni vidik, pri katerem se učenec nauči govoriti, poslušati, brati in pisati v tujem jeziku.

Pri načrtovanju posamezne ure tujega jezika morajo biti opredeljeni vsi štiri vidiki izobraževanja. (Passov, Kuzovleva, 2010b: 10)

\subsection{Spoznavni vidik}

Učenec pri pouku tujega jezika spoznava ciljni jezik in kulturo. Brez kulture ni mogoče spoznati jezika. Zavedati se je potrebno, da sta jezik in kultura nedeljiva dela iste celote, zato mora biti tudi tuja kultura, katere del je tuji jezik, vključena v izobraževanje. Kulturo kot cilj izobraževanja Passov razume kot individualno usvojen sistem duhovnih vrednot. Učenec mora preko različnih dejavnosti spoznavati tujejezično kulturo in na takšen način razvijati svojo osebnost ter duhovnost.

Kulturo in njene vrednote, s pomočjo katerih poteka primarna socializacija, je potrebno razumeti kot izhodišče, na katerem raste zavest in znanje o maternem jeziku. Omenjeno je potrebno upoštevati ter prenesti tudi v pouk tujega jezika, saj je eden od ciljev tujejezičnega izobraževanja oblikovanje duhovnega človeka. Učenje tujega jezika torej ni le sprejemanje novega znanja, ampak mora nuditi tudi pogoje za osebnostno rast učencev. Kultura (dejstva o kulturi in zgodovini naroda) je sestavni del vsebine izobraževanja, jezik pa njen neločljivi del (npr. angleški čas Present Simple je potrebno razumeti kot dejstvo kulture). Podatke, povezane s ciljno kulturo, učenec pri pouku tujega jezika usvaja ob uporabi jezika (govorne produkcije), hkrati pa na osnovi usvojenih dejstev izboljšuje svoje jezikovno znanje. Vsebino spoznavnega potenciala lahko pri učni uri posredujemo na različne načine, in sicer (Passov, Kuzovleva 2010b; 15-16):

1. preko prikazovanja dejanske resničnosti, predstavljene predmetno (fotografije, ilustracije, risbe, sheme, plakati, dokumentarni filmi ...),

2. preko prikazovanja dejanske resničnosti, prestavljene predmetno-verbalno v obliki tekstov (televizijski programi, gledališke vstopnice, deklaracije na različnih izdelkih, ankete, meniji, ceniki, recepti ipd.),

3. preko posredovanja dosežkov umetnosti (slike, reprodukcije, plakati, spomeniki ...),

4. preko književnosti, s katero posredujemo običaje in tradicije določenega naroda,

5. s pomočjo priročnikov, enciklopedij, znanstvene literature ipd. (zemljevid podzemne železnice, načrti, vodniki ...),

6. preko množičnih medijev (televizijske in radijske oddaje, časopisi, revije ...), 
7. preko besedil oz. tekstov (avtentični teksti in izjave nositeljev jezika o svoji kulturi, odnosu do kulture ipd.),

8. preko sporazumevanja z učiteljem kot prenašalcem in interpretatorjem tuje kulture,

9. preko tujega jezika kot sestavnega dela kulture (znanje o jezikovnem ustroju).

\subsection{Razvojni vidik}

Učenci v osnovnih in srednjih šolah so velikokrat nemotivirani in nezainteresirani za učenje tujih jezikov. Učenje tujega jezika je za takšnega učenca prisila, nepotrebna obveznost, pridobljeno znanje pa povsem brez smisla. Razvojni vidik vključuje tudi osebnostni razvoj učencev. Delo v razredu mora potekati v skladu z osebnostnimi značilnostmi učencev. Pri pouku je potrebno obravnavati življenjsko aktualne teme in izražati mnenje ter odnos do njih. Učenec mora začutiti, da je spoštovan, zato morata biti učenec in učitelj pri pogovoru v enakovrednih položajih. Pouk tujega jezika, kot ga razume Passov, je pouk, ki temelji na sporazumevanju oz. komunikaciji. Preko različnih sredstev sporazumevanja učenec spoznava kulturne vrednote tujega naroda, vendar vedno v dialogu z izhodiščno (materno) kulturo. Vstop v svet tuje kulture pomembno prispeva k razvoju osebnosti učenca kot subjekta izhodiščne kulture. Razvojni vidik predstavlja razvoj sposobnosti učenca (osmišljanje prejetega, slušna in vizualna dieferenciacija, razvoj pozornosti, reproduktivnih in produktivnih dejavnosti, izražanje mnenj, čustev ipd.) ob spoznavanju tuje kulture. Z razvojem sposobnosti razvijamo učenčevo osebnost ter ga pripravljamo na samostojno učenje.

Prikaz 1: Razvoj osebnosti učencev v procesu tujejezičnega izobraževanja (Passov, Kuzovleva, 2010: 73).

Razvoj osebnosti

\begin{tabular}{|c|c|c|}
\hline \multicolumn{3}{|c|}{$\begin{array}{l}\text { Lastnosti človeka: anatomija, fiziološke značilnosti, posebnosti živčnega sistema, delovanje } \\
\text { spomina, nagnjenja ipd. }\end{array}$} \\
\hline \multicolumn{3}{|c|}{$\begin{array}{l}\text { Aktivnosti, s pomočjo katerih se dogaja razvoj: } \\
\text { IGRA, UČENJE, DELO, SPORAZUMEVANJE }\end{array}$} \\
\hline \multicolumn{3}{|c|}{ Področja duševnosti, ki sodelujejo v interakciji z zunanjim svetom: } \\
\hline Spoznavno področje & $\begin{array}{l}\text { Emocionalno področje in } \\
\text { oblikovanje mnenj }\end{array}$ & $\begin{array}{l}\text { Udejstvovanje in } \\
\text { preoblikovanje }\end{array}$ \\
\hline \multicolumn{3}{|c|}{$\begin{array}{c}\text { KULTURA, } \\
\text { ki jo usvaja individuum kot subjekt izobraževalnega procesa }\end{array}$} \\
\hline $\begin{array}{l}\text { Podoba sveta } \\
\text { ('vedeti') }\end{array}$ & $\begin{array}{l}\text { Sistem vrednot } \\
\text { ('želeti') }\end{array}$ & $\begin{array}{l}\text { Vrste dejavnosti } \\
\text { ('znati') }\end{array}$ \\
\hline \multicolumn{3}{|c|}{ Ustvarjanje ('ustvarjati') } \\
\hline \multicolumn{3}{|c|}{ Individualnost učenca kot cilj - ideal (homo moralis) } \\
\hline
\end{tabular}




\subsection{Vzgojni vidik}

Tudi vzgojni vidik je povezan z usvajanjem kulture in ga je potrebno razumeti kot proces, pri katerem se bogati in izpopolnjuje duhovni svet človeka. S spoznavanjem in osmišljanjem nove kulture, ki potekata $\mathrm{v}$ dialogu $\mathrm{z}$ izhodiščno kulturo, bogatimo duhovnost učencev.

Vzgojni vidik se razkriva v vsebini učnega gradiva, mnenjih učitelja, v samem načinu sporazumevanja. Učitelj mora pri svojem delu upoštevati etična načela in vzgajati duhovnega človeka. Duhovnega človeka Passov opredeli z naslednjimi značilnostmi (Passov, Kuzovleva 2010b: 30):

- pozitivno gleda na domovino (patriotizem in aktivna udeležba pri razvoju države),

- $\quad$ spoštuje življenje kot vrednoto (želja po reševanju konfliktov, kriz, spoštljiv odnos do narave),

- $\quad$ sprejema svetovno kulturo kot vrednoto (razvijanje čustva internacionalizma),

- $\quad$ spoštuje človekove svoboščine in pravice (osebno dostojanstvo, pravičnost),

- komunicira in sodeluje (razume drugačne poglede, izraža željo po doseganju konsenzov in kompromisov).

Med učencem in učiteljem mora potekati t. i. pedagoško sporazumevanje (rus. педагогическое общение), ki poudarja enakovreden odnos vseh udeležencev v komunikaciji, poleg tega pa mora posnemati realni proces sporazumevanja.

\subsection{Učni vidik}

Učni vidik obsega vse štiri jezikovne dejavnosti (branje, pisanje, poslušanje, govor), komunikacijske veščine ter znanja o tem, kako se učiti. Vse našteto se v komunikacijski teoriji Passova podreja skupnemu cilju, tj. uspešnemu sporazumevanju v drugi kulturi. Proces oblikovanja jezikovnih navad in razvoj jezikovnih veščin je proces, ki sodi v širši kontekst razvoja celostnega jezikovnega mehanizma, ta pa predstavlja hkrati tudi proces razvoja osebnosti. (Passov, Kuzovleva, 2010: 86)

Vsebina tujejezičnega izobraževanja je kultura, ki jo Passov imenuje tujejezična kultura (rus. иноязычная культура) in je del splošne kulture človeštva. Učenec jo usvaja v procesu komunikacijskega tujejezičnega izobraževanja v skladu z opisanimi štirimi vidiki. Tujejezično kulturo moramo razumeti kot sredstvo, s katerim dosegamo zastavljene izobraževalne cilje (izoblikovanje duhovnega človeka, dialog kultur). Usvojitev tujejezične kulture je osnovano na integraciji štirih osnovnih načel (Passov, Kuzovleva, 2010b: 43):

1. znanje o tuji kulturi moramo uporabiti v dialogu z materno kulturo (spoznavni vidik);

2. pri sporazumevanju moramo uporabljati različne sposobnosti (razvojni vidik);

3. realizirati moramo nravstveni potencial tujejezičnega izobraževanja (vzgojni vidik);

4. znati se moramo sporazumevati z uporabo vseh jezikovnih dejavnosti (učni vidik). 
Integracija omenjenih načel omogoča dolgotrajni dialog kultur, saj je skupni cilj izobraževanja t. i. homo moralis, cilj tujejezičnega izobraževanja pa razvoj individualnosti učencev kot moralnih osebnosti, ki bodo pripravljeni na dialog med različnimi kulturami. (Passov, Kuzovleva 2010b: 49)

\section{METODIČNA VSEBINA URE TUJEGA JEZIKA}

Metodična vsebina ure tujega jezika, kot jo imenuje Passov, je skupek znanstvenih tez, ki opredeljujejo posebnosti, strukturo, logiko in način dela. Pouk tujega jezika je potrebno organizirati tako, da bo kar se da podoben realnemu medkulturnemu sporazumevanju oz. dialogu kultur. Pri tem je potrebno upoštevati nekaj osnovnih principov, ki pomagajo učitelju pri organizaciji in vsebini učnega procesa. (Passov, Kuzovleva 2010b: 51)

\subsection{Princip organizacije izobraževalnega procesa kot modela sporazumevanja}

Pedagoško sporazumevanje je takšno sporazumevanje učitelja z učenci, ki ustvarja najboljše pogoje za njihov razvoj, sprejemanje kulturnih vrednot, ustvarjalno delo in prijetno klimo v razredu. Pri interakciji z učenci so izražene tudi osebnostne lastnosti učitelja.

Pri pouku tujega jezika je potrebno komunicirati. Učenci so enakovredni partnerji v procesu sporazumevanja. Učitelj mora sestopiti s svojega nadrejenega položaja in postati učencem enakovredni komunikacijski partner. Učitelj daje replike, ki govorijo o njegovem odnosu do obravnavanega problema in spodbujajo komunikacijo. Napak med samim sporazumevanjem ne popravljamo neposredno, ampak s pomočjo parafraz ipd. Sporazumevanje mora imeti osebno noto, ne sme biti le igranje vlog. Učitelj mora v učencu videti osebnost, govoriti mora naravno in vztrajati v tem pristopu, upoštevati interese sogovornika, biti iskren, upoštevati mora mimiko, geste, intonacijo, biti dobronameren (ne sme se posmehovati učencem zaradi storjenih napak, uporabljati grobih besed ali privzdigovati glas), poleg tega pa mora spreminjati položaje v razredu (stati, sedeti, se gibati). Da lahko učitelj postane učencem v procesu komunikacije enakovredni partner mora imeti: a) perceptivne komunikacijske veščine (upoštevanje psihičnega stanja učencev, vzdušja v razredu, zmožnost videti posameznika in hkrati celotno skupino, biti pozoren na šibkosti posameznikov ...) in b) produktivne komunikacijske veščine (ustvariti komunikacijsko prijetno vzdušje, vzpostaviti stik z učenci ipd.). (Passov, Kuzovleva 2010b)

Pri vzpostavljanju modela sporazumevanja je zlasti pomembno, kako začnemo šolsko uro. Začetek posamezne šolske ure je uvod v atmosfero tujejezičnega sporazumevanja, z njim povečamo motiviranost učencev. Pri tem morajo biti vprašanja in stavki, ki jih uporablja učitelj, kar se da naravni, torej takšni, kakršne uporabljamo pri vsakodnevni komunikaciji. 


\subsection{Princip individualizacije}

Individualnost učenca Passov razdeli na tri podvrste, in sicer na: individualizacijo individuuma (temperament, potrebe organizma ...), individualizacijo subjekta (učne strategije, pristopi ...) in individualizacijo osebnosti (učenčevi interesi, želje, čustva ...).

$\mathrm{Z}$ individualizacijo individuuma učitelj razvija učenčeve sposobnosti in pri tem upošteva oz. uporablja (Passov, Kuzovleva 2010b: 79-81):

- dodatno pomoč za slabše učence,

- različne vrste pripomočkov in mnemotehničnih sredstev,

- posebni vrstni red vprašanj (najprej zastavi vprašanje najboljšim, šele nato slabšim učencem ali obratno),

- čas za pripravo odgovora (slabšim učencem ponudi več časa za pripravo odgovora),

- individualno zasnovane naloge (slabšim učencem pomaga z za to posebej pripravljenimi pripomočki, ki jim omogočajo hitrejše usvajanje gradiva),

- naloge različnih težavnostnih stopenj (npr. različno zahtevne domače naloge),

- dodatno gradivo za boljše učence,

- $\quad$ pomoč dobrih učencev, ki snov razložijo slabšim (teh veščin se morajo pri pouku priučiti),

- pogosteje sprašuje slabše učence,

- dodatne naloge za tiste, ki imajo težave na specifičnem področju.

Ker se sposobnosti posameznika neprestano razvijajo, je uspeh možen le z rednim delom. Za učence, ki imajo težave in so slabo motivirani, lahko učitelj pripravi dodatne vaje, ki jim bodo neposredno pomagale, da se pripravijo na naslednjo uro. Učenci bodo zato lažje sodelovali, ne bodo (negativno) izstopali, poleg tega pa se bo njihova motiviranost izboljšala.

Pri uri tujega jezika modeliramo realno komunikacijsko situacijo, v kateri so vsi udeleženci enakovredni. Še zlasti je pomembno, da v omenjeni proces pritegnemo slabše učence, ki ponavadi ostajajo tiho.

$\mathrm{Z}$ drugim tipom individualizacije $-\mathrm{z}$ individualizacijo subjekta - učitelj podaja metajezikovno znanje o učenju in navaja učence na samostojno učenje.

Z individualizacijo osebnosti, ki je za Passova najpomembnejša, pa učitelj splošne vrednote spreminja $v$ osebne in s tem znanje tujega jezika spreminja v osebno vrednoto. Posameznega učenca je potrebno razumeti kot samostojno osebnost, z lastnimi interesi, izkušnjami in željami. Priporočljivo je, da pred začetkom nove teme učitelj izvede kratko anketo, ki mu bo omogočila, da bo v nalogah upošteval značilnosti posameznika in tako vzdrževal visoko komunikacijsko motiviranost. Izvedba omenjene ankete, ki je povezana z novim vsebinskim sklopom, vzame 10-15 minut, učenci lahko odgovorijo na vprašanja $\mathrm{v}$ šoli, in sicer nekaj ur pred uvedbo omenjene nove teme, ali pa anketo rešijo v obliki domače naloge. Če je naslednji tematski sklop povezan s 
potovanji, lahko anketa vsebuje vprašanja, kot so: Ali si že bil/a v Londonu?, Kako si pripotoval/a v London?, Ali si si že ogledal/a kakšno oddajo, posvečeno Londonu?, O čem je govorila?, Ali poznaš kakšno londonsko znamenitost?, Katero? ... Podatki, pridobljeni s pomočjo anket, so učitelju v veliko pomoč pri izbiri vsebine jezikovnega materiala, ki ga bodo uporabljali učenci v komunikacijskem procesu, ter pri pripravi potrebnega gradiva (slike, teksti ...), s katerim bo spodbujal komunikacijo in motivacijo. K motivaciji pomembno prispevajo tudi dogodki, povezani s tujim jezikom ali tujejezično kulturo, ki se odvijajo izven razreda. Učencem moramo z dejstvi, torej konkretno, predstaviti, zakaj je znanje tujega jezika pomembno pri njihovi nadaljnji poklicni karieri in osebnostni rasti.

\subsection{Princip govorno-miselne dejavnosti (rus. речемыслительная активность)}

Pri učenju morajo biti učenci aktivni, ustvarjalni in samostojni. Pri produkciji govora je potrebno poudariti miselno delo (ne zgolj ponavljanje za učiteljem), ki se izvaja kot notranja aktivnost. Učenec je notranje aktiven, ko v svoji notranjosti misli in govori. To pomeni, da je učenec aktiven, čeprav je tiho. Da bi učitelj tujega jezika omogočil notranjo miselno aktivnost učencev, mora natančno in konkretno določiti cilje posamezne ure in uporabljenih nalog, gradivo, namenjeno spodbujanju govorne produkcije, različne pristope k obravnavani snovi, lastne čustvene odzive ipd.

Glavni stimulator govorno-miselne aktivnosti je t. i. govorno-miselna naloga (rus. речемыслительная задача), pri kateri je najpomembnejše, to da učenec razloži svoj odnos do obravnavane stvari ali problema. Učitelj je tisti, ki s svojimi vprašanji, izzivanjem in izjavami učence pripravi do tega, da želijo izraziti svoje mnenje o zadevi (primer naloge - Včeraj sem izvedela, da vaš sošolec ni hotel razložiti sošolcu, ki je bil cel teden odsoten, nove snovi in mu pomagati pri reševanju nalog. Kaj menite o tem?) Oblikovanje takšnih nalog ni enostavno, pa tudi njihovo reševanje za učence ni preprosto. $Z$ uporabo omenjenih nalog razvijamo produktivno stran razmišljanja. Na takšen način postane učenec subjekt v procesu učenja.

Govorno-miselna dejavnost zahteva intelektualni trud učencev, ki spodbuja tudi samostojno razmišljanje in izražanje lastnega mnenja. Govorno-miselno aktivnost je potrebno razvijati in vaditi. Učenec mora aktivno uporabljati tuji jezik. Najbolj učinkovito sredstvo za razvoj in oblikovanje tujejezičnega govora je njegova neposredna uporaba na osnovi govorno-miselne dejavnosti. Govorno-miselna dejavnost je torej lahko: a) zunanja (ko učenec dejansko govori) in b) notranja (učenec sicer molči, vendar v sebi vzpostavlja odnos do predstavljene govorno-miselne naloge). Pri uri tujega jezika lahko govori naenkrat samo en učenec, ostali pa morajo biti notranje aktivni. Učitelj mora kar se da pogosto spodbujati govorno-miselno aktivnost učencev ob pomoči komunikacijskih nalog. Proces sporazumevanja v razredu mora biti v največji možni meri preslikava takšnega procesa 
v realnem svetu (ne pa lekcij iz učbenika), zato moramo pri komunikacijskih nalogah uporabljati vsebine, ki se uporabljajo v realni komunikaciji.

Za razvoj govorno-miselnih dejavnosti učencev je pomembno zlasti:

- redno spodbujanje govorne produkcije na osnovi govorno-miselnih nalog,

- $\quad$ vsako posamezno govorno dejanje mora biti motivirano in naravnano tako, da govorec z njim vpliva na ostale udeležence v komunikaciji;

- $\quad$ posamezna ura tujega jezika mora biti zamišljena, organizirana in izvajana kot ura tujejezičnega govora. (Passov, Kuzovleva, 2010b: 108)

\subsection{Princip funkcionalnosti}

Princip funkcionalnosti določa učne dejavnosti, ki jo izvajajo učenci in učitelj, ter oblike in vsebine omenjenih dejavnosti. Razumemo ga lahko v skladu z naslednjimi vidiki (Passov, Kuzovleva, 2010b):

1. Funkcionalnost kot osnova modeliranja govornega materiala (učitelj modelira, tj. izbere in organizira govorno gradivo - ustvari sistem govornih sredstev, ki je poenostavljen do te mere, da ga učenci lahko usvojijo in hkrati omogoča realizacijo osnovnih govornih funkcij v procesu sporazumevanja; npr. učitelj razloži/uporabi le tiste oblike izražanja začudenja v tujem jeziku, ki jih bodo učenci s trenutnim znanjem razumeli in zmogli uporabljati);

2. Funkcionalnost in govorne enote (učitelj opredeli konkretne govorne enote, ki so del prej omenjenega sistema govornih sredstev, torej besede, besedne zveze, fraze ipd.);

3. Funkcionalnost pri izboru in organizaciji gradiva - obravnavati in izbrati je potrebno gradivo, ki se uporablja pri komunikaciji (npr. če učbenik, namenjen prvemu letu učenja tujega jezika, vsebuje samo razlago in uporabo sedanjika/ov, je potrebno premisliti, ali je to umestno in ali se lahko sporazumevamo brez uporabe preteklika in prihodnjika);

4. Funkcije govornih enot in prenos navad - govorne navade je mogoče uspešno razvijati z uporabo govorno-miselnih nalog in principa situacijskosti;

5. Funkcionalna povezanost vseh treh elementov govorne aktivnosti - govorna aktivnost vsebuje leksikalno (semantično), gramatično (strukturno) stran in izgovor. Vse tri komponente morajo delovati povezano. Besede, besedne zveze, fraze ipd. je potrebno usvajati z vseh treh vidikov hkrati kot govorne enote.

6. Funkcionalnost in usvajanje - po mnenju Passova je vrstni red, pri katerem najprej razložimo slovnična pravila (teorijo) in nato njihovo uporabo (navade), nepravilen. Slovnična pravila morajo poudarjati funkcionalnost uporabljenih govornih sredstev v procesu sporazumevanja. Učitelj mora pri podajanju snovi uporabljati za to posebej oblikovana pravila oz. navodila (rus. правила-инстркуции), ki jih učencem posreduje v procesu oblikovanja govornih navad. Omenjena navodila so operativna, posplošena in funkcionalna (npr. Če želiš pripovedovati o svojih prihodnjih načrtih, uporabljaj obliko ... ali Če pripovedujete o tem, kaj običajno delate, glagol dobi končnico ...). Za 
vsako govorno enoto je potrebno posebej določiti, katera pravila oz. navodila bomo uporabili, njene posebnosti, pojavljanje v različnih situacijah, podobnosti/razlike z maternim jezikom ipd. Razlage in navodila se učencem posredujejo postopoma.

7. Funkcionalnost in prevod - materni jezik moramo pri pouku tujega jezika uporabljati kot pripomoček in tako ozaveščati razlike in podobnosti med izhodiščnim in tujim jezikom. Pri učenju tujega jezika ne uporabljamo nalog prevajanja, saj sta prevajanje in govor povsem različni dejavnosti. Prevajanje je zahtevno, vzame veliko časa, učenci naredijo pri tem veliko napak, vse omenjeno pa preprečuje, da bi pri učencih učinkovito razvijali govorne navade in veščine.

\subsection{Princip situacijskosti}

Vaje in teksti, ki jih uporabljamo pri pouku tujega jezika, velikokrat vključujejo osebe, predmete in vsebine, ki jih $\mathrm{v}$ realnih komunikacijskih situacijah redko srečamo. Komunikacijska situacija pomeni sistem medsebojnih odnosov, ki se ustvarijo med udeleženci v določeni situaciji. Učitelji tujih jezikov poznajo primere, ko učenci poznajo besede, ravno tako tudi njihove slovnične lastnosti, ne zmorejo pa omenjenega znanja izraziti $v$ govoru. Znanja ne zmorejo prenesti v govor, ker jim manjka prožnosti (rus. гибкость). Prožnost pa se oblikuje le v situacijskih pogojih, tj. ob uporabi govornih enot v več podobnih situacijah. (Passov, Kuzovleva 2010b)

Ob upoštevanju medosebnih odnosov v procesu komunikacije se realizira strategija, taktika govorečega in govorna produkcija. V takšni komunikacijski situaciji je mogoča govorna samostojnost učenca (brez uporabe dodatnih pripomočkov in opor). Tako razumljena situacijskost vključuje tudi individualizacijo osebnosti.

\subsubsection{Situacija kot osnova učnega procesa}

Po mnenju Passova je situacija stvar osebnega dojemanja in odnosa do določene vsebine. Situacija je hkrati prostor, v katerem se dogaja medosebna komunikacija. Situacijo je potrebno organizirati kot aktivnost, pri kateri se rešuje govorne naloge (npr. prositi nekoga za pomoč ...). Situacija je dinamična in se z vsako repliko v komunikacijskem procesu spreminja ter tako napreduje $v$ nekaj neponovljivega. Passov definira situacijo kot dinamični sistem odnosov med udeleženci v komunikaciji, ki v njihovi zavesti porodi in vzdržuje osebno potrebo po dejavnosti, ki je usmerjena k cilju, tj. k reševanju govorno-miselnih nalog. (Passov, Kuzovleva 2010b: 130)

Odnosi med udeleženci so lahko različni, zato Passov opredeli štiri tipe komunikacijskih odnosov, ki so med seboj tesno prepleteni (Passov 2010b: 131-133):

a) statusni odnosi, pri katerih je poudarjen socialni status subjektov v komunikaciji (npr. kmet, študent ...) - situacije, v katerih uporabljamo statusne odnose imenujemo situacije socialno-statusnih odnosov; 
b) igra vlog - igro vlog lahko uporabimo pri formalnem in neformalnem sporazumevanju (npr. šef-podrejeni, sporazumevanje med vrstniki ...);

c) odnosi, ki se vzpostavijo pri skupni aktivnosti (npr. skupina učencev skuša prepričati drugega učenca, da gre z njimi v kino);

c) nravstveni odnosi - ker sporazumevanje poteka med osebami, je v procesu komunikacije vedno prisotna moralna komponenta.

$\mathrm{V}$ procesu sporazumevanja se situacija kot sistem medosebnih odnosov ne vzpostavi sama, ampak kot rezultat celotnega spleta objektivnih in subjektivnih dejavnikov, ki jih Passov imenuje situacijska pozicija (rus. ситуативная позиция). (Passov, Kuzovleva 2010b)

Situacijska pozicija je integracija objektivnih in subjektivnih komponent, prisotnih v procesu sporazumevanja, ki se kažejo kot rojevanje in aktualizacija odnosov med subjekti. (Passov, Kuzovleva 2010b: 135) Situacijsko pozicijo sestavlja več elementov, ki jih moramo razumeti kot elemente realnega procesa sporazumevanja (vrsta dejavnosti, področje dejavnosti, oblika dejavnosti, tema, moralni odnosi, socialni status subjekta, dogodek, kraj, čas, morebitne tretje osebe, komunikacijska naloga ipd.). Medosebni odnosi subjektov v komunikaciji povezujejo situacijske pozicije subjektov v situacijsko celoto. Situacijsko pozicijo lahko razumemo kot sistem dejavnikov pri posameznem subjektu komunikacije, več takšnih pozicij pa vzpostavlja situacijo. Učitelj mora opredeliti elemente situacijske pozicije, ki bodo služili za oblikovanje določene situacije v učnem procesu. Glede na vrsto situacije učitelj izbere različne komponente in opredeli njihovo pomembnost. Posameznim učencem razložimo določene situacijske pozicije, nato pa se ob interakciji omenjenih pozicij vzpostavi situacija. Omenjeni način dela omogoča vnaprejšnje načrtovanje potrebnih ali želenih situacij pri pouku.

Situacija je univerzalna oblika delovanja sporazumevalnega procesa, ki obstaja kot integrativni dinamični sistem različnih odnosov med subjekti v komunikaciji (socialno-statusni odnosi, igra vlog, skupne dejavnosti, odnosi pri skupnih aktivnostih, nravstveni odnosi), se kaže v njihovi zavesti in se vzpostavlja na osnovi vplivanja ene situacijske pozicije na drugo. (Passov, Kuzovleva 2010b: 136-137)

\subsubsection{Situacija kot osnova za izbor in organizacijo jezikovnega gradiva}

Za izbor in organizacijo govornega materiala so ponavadi odgovorni avtorji učbenikov. Passov pri tem opozarja na pomembnost komunikacije. Učbeniki so običajno tematsko razdeljeni, zato resnična komunikacija ostaja šele na drugem mestu. Vsebina gradiva mora pozornost preusmeriti na komunikacijske situacije.

\subsubsection{Situacija kot način predstavljanja gradiva}

Učencem je potrebno novo snov, material ali gradivo predstaviti v situacijskih pogojih. Prvi stik z novim gradivom je izredno pomemben. Nove vsebine morajo delovati $\mathrm{v}$ 
govoru. Primarna mora biti funkcionalna stran novega, torej njegova uporaba, prikazana v situaciji - situacijska predstavitev (rus. ситуативная презентация). Govorne enote, ki niso del situacije, se ne ohranijo v spominu. Četudi si jih bo učenec zapomnil, omenjenih enot ne bo sposoben uporabiti, ker ne omogočajo asociativnih zvez s situacijo.

\subsubsection{Situacija kot pogoj za oblikovanje navad}

Kot rečeno, se prenos znanja iz sprejemanja v produkcijo zgodi ob upoštevanju situacijskosti. Učitelj mora poskrbeti za raznovrstne govorne situacije, $v$ katerih bodo učenci uporabljali neko govorno enoto. $Z$ uporabo $v$ različnih situacijah bodo učenci začeli govorno enoto uporabljati avtomatizirano.

\subsubsection{Situacija kot pogoj za razvoj veščin}

Situacije, uporabljene v razredu, morajo biti kar najtesneje povezane z dejanskimi dogodki in vsebinami iz zunanjega sveta. Zato je potrebno pri pouku tujega jezika vzpostaviti kontekst resničnosti. Tu si učitelj lahko pomaga s posebnimi kratkimi nekajminutnimi filmi, ki predstavljajo dogodek/ke, so vsebinsko zanimivi, usmerjeni k razvijanju komunikacije ipd. Takšen film si učenci ogledajo pred začetkom novega tematskega cikla, dogodki iz filma pa služijo učitelju kot osnova za oblikovanje situacij v razredu. Gradivo, ki ga pri pouku tujega jezika beremo, ne sme biti cilj, ampak sredstvo za obvladovanje govora. Besedila naj se opirajo na vsebino filmov, jo razširjano, poglabljajo in razvijajo.

Situacijskost kot element metodične vsebine pouka tujega jezika lahko opredelimo z naslednjimi glavnimi značilnostmi:

- komunikacijska situacija je lahko vzpostavljena le, če izhaja iz medosebnih odnosov udeležencev v procesu sporazumevanja;

- $\quad$ vsaka fraza, uporabljena pri pouku tujega jezika, mora biti situacijska, torej v skladu z medsebojnimi odnosi udeležencev v sporazumevalnem procesu;

- $\quad$ situacijskost je pogoj za razvoj govorne produkcije in igra pomembno vlogo v procesu oblikovanju navad. (Passov, Kuzovleva, 2010b: 141)

\subsection{Princip novosti}

Passov pri učenju tujega jezika nasprotuje veliki količini pomnjenja pravil in novih besed ter uporabi nalog, kot so Naučite se naslednje besede ali Preberite in obnovite zgodbo. Po njegovem mnenju je učinkovitejša t. i. nehotena zapomnitev (rus. непроизвольное запоминание).

Pri nehoteni zapomnitvi je snov podana v sklopu aktivnosti. Pri tem učencu niso posredovana navodila o tem, kaj točno si mora zapomniti. Pomnjenje je stranski produkt dejavnosti z gradivom (besedami, tekstom ipd.). Učencu dajemo naloge, ki 
obravnavano gradivo osvetlijo z različnih pozicij (npr. Poišči fraze/besede, ki opredeljujejo ..., Kaj je najbolj značilno za ...). Gradivo, predelano na takšen način, je vedno operativno, do njega učenec hitro dostopa v različnih komunikacijskih situacijah. Ponavljanje snovi pri pouku tujega jezika ne sme biti namenjeno samemu sebi. Snov, ki se ponavlja, mora biti vključena $\mathrm{v}$ strukturo pouka, torej v nov kontekst, $\mathrm{v}$ novo situacijo, $\mathrm{v}$ nove kombinacije. Na takšen način učenci ne samo ponavljajo, ampak hkrati tudi izpopolnjujejo znanje. Takšno ponavljanje je pred učenci skrito, vendar se neprenehoma dogaja. Vsaka posamezna šolska ura je, kot pravi Passov, ponavljanje brez ponavljanja. (Passov, Kuzovleva, 2010b: 149)

Pri učenju govora je potrebno upoštevati tudi princip novosti, ki ga uvedemo z različnimi govornimi situacijami, zamenjavo elementov situacijskih pozicij ipd. Na takšen način pripravimo učence na sporazumevanje $\mathrm{v}$ dejanskih komunikacijskih situacijah. Sporazumevanje je po svoji naravi hevristično, zato moramo omenjeno lastnost upoštevati pri govornih nalogah (možnost različnih kombinacij v različnih situacijah), predmetu sporazumevanja (prehajanje od ene teme k drugi), vsebini sporazumevanja (posamezni predmet sporazumevanja je lahko predstavljen na različne načine), obliki izjav (v procesu sporazumevanja vedno znova uporabljamo in oblikujemo nove izjave v skladu z dano situacijo) ter pri ostalih udeležencih v procesu komunikacije (pobudnik govora je lahko ena oseba, lahko pa je iniciativa gibljiva in prehaja $\mathrm{z}$ ene na drugo osebo).

Novost, vključena $\mathrm{v}$ vsebino učnega materiala, $\mathrm{v}$ nove oblike in načine dela $\mathrm{v}$ razredu, spodbudi in ohranja motivacijo učencev. Element novosti pri pouku tujega jezika mora biti posredovan redno, $\mathrm{v}$ zmernih količinah ter $\mathrm{v}$ vseh elementih učnega procesa.

Passov opredeli pet vidikov novosti, ki jih je potrebno upoštevati pri pouku tujega jezika.

\subsubsection{Novost kot osnova za gibčnost navad}

Govorne navade vsebujejo elemente, ki se spreminjajo, in tiste, ki se ne (invariante). Da bi ustvarili govorne navade, ki jih bo možno prenesti (bodo fleksibilne) v nove situacije, moramo v procesu avtomatizacije uporabljati določeno količino variantnega govornega materiala, ki bo zadostovala za oblikovanje invariantnega, tj. posplošenega govornega modela. (Passov, Kuzovleva, 2010: 150)

\subsubsection{Novost kot osnova za dinamičnost veščin}

Delo v razredu mora biti organizirano, tako da omogoča variantnost situacij in kombinacij. V govorni situaciji lahko spreminjamo govorno nalogo, dogodek, ki vpliva na odnose med udeleženci, število udeležencev, njihovo sestavo, posamezne okoliščine ter lastnosti posameznika. Nobena situacija ni ponovljiva. Različne variante razvijajo dinamičnost govorne produkcije. Za razvoj govora je potrebno neprestano variirati s komunikacijskimi situacijami, saj se tako ustvarja dinamika govora. 


\subsubsection{Novost, spomin in mišljenje}

Pri pouku tujega jezika je potrebno upoštevati nehoteno pomnjenje, ki se zgodi ob vzpostavitvi odnosov (med učenci ali med učenci in materialom) pri reševanju nalog $\mathrm{v}$ komunikacijskih situacijah. Nehoteno pomnjenje je boljše, če nas kaj moti ali nam kaj pomaga pri doseganju želenih rezultatov. Material, ki ga uporabljamo za razvoj govora, si učenec zapomni tako, da ga ponovno uporabi pri reševanju različnih govorno-miselnih nalog, torej nehote.

\subsubsection{Novost kot osnova za produkcijo govora}

Pri pouku tujega jezika mora imeti glavno vlogo mišljenje (produktivna dejavnost) in ne spomin (reprodukcija). Variantnost govornih situacij omogoča razvoj zmožnosti parafraziranja in kombiniranja. Variiranje govornih situacij in nadzor nad uporabo govornega materiala v omenjenih situacijah sta glavni sredstvi za uspešno govorno produkcijo. (Passov, Kuzovleva, 2010b: 155)

\subsubsection{Novost kot osnova motivacije}

Da bi motivirali učence, je potrebno princip novosti uporabljati neprestano, in sicer pri več elementih:

- novosti v vsebini materialov, problemov, njihovo variiranje in kombiniranje,

- nove oblike pouka (diskusije, tiskovne konference) in metode dela,

- variiranje govornih situacij in njihovih elementov,

- novosti v uporabi različnih tehničnih pripomočkov, vizualni predstavitvi ipd.

Za razvoj govora je potrebno $v$ pouk tujega jezika redno vnašati elemente novosti, in sicer v vse njegove sestavne elemente. (Passov, Kuzovleva, 2010b: 156)

\section{LOGIKA POUKA TUJEGA JEZIKA}

Logika pouka tujega jezika je povezana s strukturo, tj. notranjim bistvom pouka. Passov logiko pouka razloži s pomočjo štirih vidikov, ki morajo biti pri pouku tujega jezika vedno prisotni.

\subsection{Usmerjenost k cilju}

Vse, kar se pri pouku tujega jezika počne, mora biti podrejeno določenemu cilju, ki ga je potrebno natančno definirati. 
Prikaz 2: Shema ure, ki ustreza vidiku usmerjenosti k cilju (Passov, Kuzovleva, 2010b: 159-160)

Tema ure: pravljica

Cilj ure: učni - razvoj govornih veščin (naloge: razvoj logičnosti pripovedi; pripovedovanje po vnaprej pripravljenem načrtu); vzgojni - razvoj pozitivnega odnosa do branja Potek ure:

\begin{tabular}{|l|l|l|}
\hline 1. & 5 minut & $\begin{array}{l}\text { Govorna vaja v obliki vprašanj in odgovorov (npr. Imaš rad pravljice?, Kakšne } \\
\text { pravljice so ti všeč?, Čigave pravljice bereš? ...). Vprašanja morajo biti zastavljena } \\
\text { tako, da odgovori učencev vsebujejo vsaj dva stavka (npr. Zelo rad berem } \\
\text { pravljice. Še posebej so mi všeč ruske pravljice.). }\end{array}$ \\
\hline 2. & 6 minut & $\begin{array}{l}\text { Ogled kratkega filma - pravljice. Učitelj na tablo zapiše 4-5 za razumevanje } \\
\text { najpomembnejših besed. }\end{array}$ \\
\hline 3. & 6 minut & $\begin{array}{l}\text { Izjave učencev (iz 2-4 stavkov) o tem, kar so videli, o njihovem odnosu do } \\
\text { junakov in dogodkov. Kot pomoč za učence (odgovarjajo npr. trije učenci) pri } \\
\text { odgovarjanju in pripovedovanju lahko učitelj pripravi posebne kartice z začetki } \\
\text { stavkov (npr. Nekoč ..., Tam ..., Enkrat pa ...). }\end{array}$ \\
\hline 4. & 10 minut & $\begin{array}{l}\text { Učitelj predstavi princip izdelave domače naloge, in sicer se sestavi načrt } \\
\text { obnove prebranega besedila (5-6 točk), ki se ga zapiše na tablo. }\end{array}$ \\
\hline 5. & 5 minut & $\begin{array}{l}\text { Učenje o tem, kako povzeti kratko vsebino poljubne pravljice (po želji) z } \\
\text { uporabo na tabli zapisanega načrta in kartic. }\end{array}$ \\
\hline 6. & 13 minut & $\begin{array}{l}\text { Nekateri učenci pripovedujejo pravljico, drugi ugibajo njen naslov in predstavijo } \\
\text { svoj odnos do povedanega. }\end{array}$ \\
\hline
\end{tabular}

Iz zgornje sheme je razvidno, da je 39 minut namenjenih neposrednemu doseganju zastavljenega cilja, naloge pa so izbrane tako, da spodbujajo razvoj logičnosti pripovedovanja.

\subsection{Celostnost}

Komponenta je strukturna enota pouka, ki vsebuje osnovne značilnosti učnega procesa kot takšnega, $\mathrm{tj}$. usmerjenost $\mathrm{k}$ določenim dejanjem in določenim rezultatom omenjenih dejanj. Celostnost pomeni upoštevanje pravilnega vrstnega reda omenjenih komponent. Komponente je potrebno definirati in opredeliti način njihove medsebojne povezanosti.

Pouka tujega jezika ne moremo razdeliti na znane faze (npr. model P-P-P), učenci morajo izvajati posamezne aktivnosti s pomočjo nalog. Tudi domača naloga ni element pouka tujega jezika, ker se izvaja izven učnega procesa. Namesto pojma 'faza' (rus. этап) je po mnenju Passova primernejša uporaba besede 'enota' (rus. звено) ali 'učna situacija' (rus. учебная ситуация). Naloge, ki jih izvajajo učenci, morajo biti podrejene cilju šolske ure. Določena količina govornega materiala, ki jo morajo učenci usvojiti, mora biti vpeta v vse komponente šolske ure. Pri vsaki naslednji enoti pouka je isti material usvojen na višji ravni. Strukturna enota/komponenta pouka je t. i. naloga (rus. упражнение), 
ki ima vse lastnosti učnega procesa. Pri reševanju naloge se izvršujejo dejanja, ki vodijo k cilju, doseženi rezultati pa se preverijo. Naloga je torej najmanjša enota šolske ure, ki ima samostojen pomen.

Izvajanje samo ene naloge še ne vodi do višje ravni obvladovanja snovi. Naloge, podobnega tipa, imenuje Passov 'blok nalog'. Naloge in bloki morajo biti ustrezno povezani $\mathrm{s}$ fazami usvajanja materiala (tj. s fazami oblikovanja navad in fazami razvoja veščin).

Ura tujega jezika mora poleg spremenljivih komponent vsebovati tudi element, ki je invarianten, in sicer ustvarjanje atmosfere tujejezičnega sporazumevanja. Uspešnost oblikovanja takšne atmosfere, ki bo izzivala učence h govoru, je odvisna od osebnostnih lastnosti učitelja, njegovega stika z učenci, komunikacijskih veščin ...

Pri pouku tujega jezika stremimo k zastavljenim ciljem, ki jih skušamo doseči preko različnih aktivnosti, in sicer s pomočjo različnih nalog in blokov nalog.

Struktura šolske ure tujega jezika vsebuje tri obvezne invariantne elemente, ki se nekoliko razlikujejo glede na pozicijo učitelja in učenca. (Passov, Kuzovleva, 2010b: 172)

Prikaz 3: Invariantni elementi v strukturi šolske ure tujega jezika

\begin{tabular}{|l|l|}
\hline Invariantni elementi s pozicije učitelja & Invariantni elementi s pozicije učenca \\
\hline $\begin{array}{l}\text { 1. Ustvarjanje atmosfere tujejezičnega } \\
\text { sporazumevanja. }\end{array}$ & 1. Vstop v atmosfero tujejezičnega \\
$\begin{array}{l}\text { 2. Prikaz funkcioniranja in uporabe materiala, } \\
\text { ki se usvaja. }\end{array}$ & 2. Ozaveščanje materiala in načinov njegove \\
3. Vodenje procesa obvladovanja materiala. & 3. $\begin{array}{l}\text { Doseganje potrebne ravni obvladovanja } \\
\text { materiala. }\end{array}$ \\
\hline
\end{tabular}

Predstavljene invariante ne smemo razumeti kot tri zaporedne enote pouka, ampak kot dele različnih komponent, ki so pri pouku tujega jezika vedno prisotne.

Strukturo pouka lahko opredelimo kot mehanizem, v skladu s katerim glede na cilj organiziramo tri osnovne invariante ter komponente. Celota ure je takšno sobivanje oz. sorazmerje komponent, ki omogoča optimalno doseganje zastavljenih ciljev. (Passov, Kuzovleva, 2010b: 172)

\subsection{Dinamika}

Dinamika ure je odvisna predvsem od pravilnega zaporedja komponent (nalog). Učitelj mora glede na učne situacije pravilno izbrati vaje $\mathrm{v}$ procesu oblikovanja navad in glede na znanje učencev.

\subsection{Povezanost}

Povezanost, ki je zadnja od lastnosti logike pouka tujega jezika, lahko razdelimo na tri podvrste, in sicer na: 
- lingvistično povezanost (nova slovnica ali nove besede morajo biti uporabljene $\mathrm{v}$ vseh govorno-miselnih nalogah);

- formalna povezanost (izvedba pouka, metode dela in način poučevanja morajo biti povezani z notranjo vsebino pouka, tj. $\mathrm{z}$ emocionalno in miselno napetostjo);

- verbalna povezanost (učiteljeve povezave med posameznimi vajami ali bloki vaj).

\section{ZAKLJUČEK}

Passov je pri učenju tujega jezika oblikoval komunikacijski pristop, pri katerem ne govorimo o učenju tujih jezikov, ampak o tujejezičnem izobraževanju, ki vključuje štiri vidike, in sicer spoznavni, razvojni, vzgojni ter učni vidik. Cilj tujejezičnega izobraževanja je oblikovati duhovnega človeka, čigar bistvo se ne skriva v njegovih kompetencah, ampak v njegovi zmožnosti obvladovanja dialoga kultur. Vsebina tujejezičnega izobraževanja pa je tujejezična kultura kot posebna integrativna duhovna substanca, ki vpliva na oblikovanje individualnosti učenca kot subjekta $v$ dialogu kultur.

Učitelj mora izobraževalni proces oblikovati kot model sporazumevanja, ki odslikava realni proces komunikacije v tuji kulturi. Pri tem so učenci in učitelj kot udeleženci v komunikacijskem procesu v enakopravnih odnosih (pedagoško sporazumevanje). Pri načrtovanju šolske ure tujega jezika mora učitelj upoštevati tudi princip individualizacije, s katerim razvija učenčeve sposobnosti in spodbuja motivacijo, ter principa funkcionalnosti in situacijskosti, princip novosti ter govorno-miselne naloge. S pomočjo slednjih učence navajamo na samostojno razmišljanje in oblikovanje lastnega mnenja, kar je iz naših šol velikokrat izključeno.

Logika učne ure tujega jezika je povezana s strukturo pouka in zajema štiri temeljne vidike: naravnanost $\mathrm{k}$ cilju, celostnost, dinamiko in povezanost.

Komunikacijska teorija Passova poudarja pomembnost govora pred ostalimi jezikovnimi zmožnostmi (pisanje, branje, poslušanje). Govorna produkcija mora biti vedno postavljena $\mathrm{v}$ določeno situacijo (kontekst), ki je model realnega procesa sporazumevanja. S pomočjo govorno-miselnih nalog morajo učenci izražati (govorno) svoja mnenja in stališča do obravnavanega problema. Učenec mora pri tem poznati določeno število besed, tvoriti stavke ipd., zato omenjeni pristop ni najprimernejši na začetnih stopnjah učenja tujega jezika. Passov ne upošteva in ne omenja t. i. tihega obdobja, v katerem učenci sicer usvajajo snov in izvajajo določene aktivnosti, niso pa še sposobni govorne produkcije. Na tem mestu se zastavlja tudi vprašanje o tem, kako naj učitelj zagotovi notranjo aktivnost vseh učencev (učenec vzpostavlja odnos do predstavljenega problema) in kako je lahko prepričan $\mathrm{v}$ to, da so učenci res notranje aktivni, ko so $\mathrm{v}$ resnici tiho.

Nekoliko poenostavljena se zdi razlaga o prenosu znanja iz faze sprejemanja novega gradiva $\mathrm{v}$ fazo uporabe, torej govora. Omenjeni proces se po mnenju Passova 
zgodi ob upoštevanju principa situacijskosti. Jezikovni material (besede, fraze ipd.) si bo učenec nehotno zapomnil, če bo omenjeni material uporabljen v različnih situacijah. Nizka stopnja motivacije, odklonilen odnos in ne nazadnje nizke sposobnosti preprečujejo takšno nehotno pomnjenje, poleg tega poznamo primere priseljencev, ki več let živijo v tuji kulturi, se znajdejo v številnih raznovrstnih situacijah, pa ne zmorejo/ nočejo govoriti v tujem jeziku.

Ruski didaktik razume učenje in poučevanje tujega jezika kot širši proces - kot t. i. tujejezično izobraževanje - pri katerem učenec spoznava tujo kulturo in jezik. Učiteljeva naloga je, da pri pouku uporablja pedagoško sporazumevanje, v katerem so vsi udeleženci komunikacijskega procesa (vključno z učiteljem) v enakovrednih položajih, ter skrbno pripravi načrt in gradivo za posamezno uro v skladu s predstavljenimi principi, vidiki in logiko učne ure. Vse omenjeno ne spodbuja le govorne produkcije učencev, ampak tudi njihovo individualno rast ter razvoj veščin za samostojno učenje.

Teorijo komunikacijskega tujejezičnega izobraževanja lahko učitelji tujega jezika s pridom uporabijo zlasti pri razvijanju govornih navad, pripravi materialov in organizaciji šolske ure, spodbujanju motivacije in aktivnem sodelovanju učencev. Kot pomembna in hkrati v sodobnem svetu nujno potrebna pa se zdi humanistična plat teorije Passova, ki pouk tujega jezika razume kot oblikovanje duhovnega oz. moralnega človeka, ki zna upoštevati tako domačo kot tujo kulturo in $\mathrm{z}$ dialogom med obema stranema razvija svojo lastno osebnost.

\section{BIBLIOGRAFIJA}

AFANAS'EVA, O. V. (2012) Metodičeskaja škola E. I. Passova i ee ispol'zovanie v sovremennoj škole. Meždunarodnnyj-gumanitarnyj lingvističeskij institut g. Moskva. http://sibac.info/index.php/2009-07-01-10-21-16/4604-2012-11-08-16-43-28.

Council of Evrope (2001) Common European Framework of Reference for Languages: Learning, Teaching, Assessment. Cambridge: Cambridge University Press.

Ministerstvo obrazovanija in nauki Rossijskoj Federacii, Negosudarstvennoe obrazovatel'noe učreždenie vysšego professional'nogo obrazovanija »Novyj gumanitarnnyj institut« (2011) Metodičeskie rekomendacii po podgotovke k itogovomu ekzamenu po discipline »Teorija obučenija inostrannym jazykam» http://www.noungi.ru/methodical\%20advices.htm.

Novyj slovar' metodičeskih terminov i ponjatij (teorija in praktika obučenija jazykam). Moskva: Ikar, 2009.

PASSOV, E. I./KUZOVLEVA, N. E. (2010) Osnovy kommunikativnoj teorii i tehnologii inojazyčnogo obrazovanija: metodičeskoe posobie dlja prepodavatelej russkogo jazyka kak inostrannogo. Moskva: Russkij jazyk. Kursy.

PASSOV, E. I./KUZOVLEVA, N. E. (2010b) Urok inostrannogo jazyka. Glossa-Press. Moskva: Feniks. Rostov-na-Donu. 
TOMIĆ, Ana (1997) Izbrana poglavja iz didaktike. Ljubljana: Center za pedagoško izobraževanje Filozofske fakultete.

VEDEL', G. E. (2001) Metody obučenija inostrannym jazykam i ih metodologičeskaja osnova.

Vestnik VGU. Serija lingvistika i mežkul'turnaja kommunikacija. B. 1. C. 85-91.Voronež. http://www.ebiblioteka.lt/resursai/Uzsienio\%20leidiniai/Voronezh/lin/2001-01/ lin0101_10.pdf

VUČO, Julijana (2012) O učenju jezikov. Pogled v zgodovino glotodidaktike: od pradavnine do druge svetovne vojne. Ljubljana: Znanstvena založba Filozofske fakultete.

\section{ABSTRACT}

\section{Theory of communicative foreign language education}

The paper presents the theoretical starting points of the theory of communicative foreign language education developed by a Russian educator and didactician E. I. Passov and presented in a monograph entitled Urok inostrannogo jazyka. The article describes the aspects of foreign language education (cognition, development, learning and training), methodical content of a foreign language lesson and elements of the "logic" of foreign language classes which teachers should take into account in order to effectively encourage the language abilities of students.

Keywords: foreign language education, foreign language culture, communication situation, oral and thinking assignment, logic of a foreign language lesson, communication in education.

\section{POVZETEK}

\section{Teorija komunikacijskega tujejezičnega izobraževanja}

V prispevku so predstavljena teoretična izhodišča teorije komunikacijskega tujejezičnega izobraževanja ruskega pedagoga in didaktika E. I. Passova, predstavljena v monografiji Urok inostrannogo jazyka. Članek opisuje vidike tujejezičnega izobraževanja (spoznavni, razvojni, vzgojni in učni), metodično vsebino učne ure tujega jezika ter prvine t. i. logike pouka tujega jezika, ki naj jih upošteva učitelj za učinkovito spodbujanje govorne zmožnosti pri učencih.

Ključne besede: tujejezično izobraževanje, tujejezična kultura, komunikacijska situacija, govorno-miselna naloga, logika učne ure tujega jezika, pedagoško sporazumevanje. 